\title{
The hidden sedimentary basin underneath the Quaternary volcanic unit in Bogor and Kendeng area
}

\author{
E. Septama ${ }^{1 \#}$, C. Prasetyadi ${ }^{2}$, A. Abdurrokhim ${ }^{3}$, T. Setiawan ${ }^{1}$, P.D. Wardaya ${ }^{1}$, R. Raguwanti ${ }^{1}$, R. Ryacudu ${ }^{1 *}$, A. $^{2}$ \\ Mulawarman $^{1}$, B. Adhiperdhana ${ }^{3}$, I. Haryanto ${ }^{3}$, M. G. Rahman², A. Novianto², J. Setiawan' ${ }^{2}$, Y. Sutadiwiria ${ }^{3}$, M. $^{2}$ \\ Syaifudin², V.I. Rossa ${ }^{1}$ and R.R. Pratama ${ }^{1}$
}

${ }^{1}$ Upstream Research and Technology Innovation (URTI), Pertamina

${ }^{2}$ Fakultas Teknologi Mineral, Universitas Pembangunan Nasional Veteran (UPN), Yogyakarta

${ }^{3}$ Fakultas Teknik Geologi, Universitas Padjajaran (UNPAD), Bandung

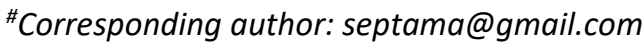

*Deceased

\begin{abstract}
Java Island is part of an active volcanic arc that experienced several volcanism episodes, which gradually moved from South to North from the Late Oligocene to Pleistocene, following the subduction of the Indian Ocean-Australian plate underneath the Eurasian plate. During the Eocene, the southern and northern parts of Java were connected as one passive margin system, with the sediment supply mainly coming from Sundaland in the north. During the Eocene-Oligocene, the subduction along Sunda-Java Trench created compressional tectonics that led to the formation of a flexural margin and a deep depression in the central axis of Java Island, which later acted as an ultimate deep-sea depocenter during the Neogene period. In contrast to the neighboring Northwest and Northeast Java Basins in the Northern edges of Java Island, the basin configuration in the East-West trending depression in the median ranges of Java (from Bogor to Kendeng Troughs) are poorly imaged by seismic due to the immense Quaternary volcanic eruption covers.
\end{abstract}

Five focus areas are selected for this study. A total of $1,893 \mathrm{~km}$ of seismic sections, 584 rock samples, 1569 gravity and magnetic measurements, and 29 geochemical samples (rocks, oil, and gas samples) were acquired during the study. Geological fieldwork was focused on the stratigraphic unit composition and the observable features of deformation products from the outcrops. Due to the scarcity of exposures of Paleogene deposits in the Central-East Java area, rock samples were also collected from the mud volcano ejected materials in the Sangiran Dome.

Copyright (C2021. FOSI. All rights reserved.

Manuscript received August $1^{\text {st }}, 2021$, revised manuscript received August 31 ${ }^{\text {st }}$,

2021, final acceptance September 18 ${ }^{\text {th }}, 2021$.

DOI: $10.51835 /$ bsed.2021.47.2.323 
The distinct subsurface configuration differences between Bogor and Kendeng Troughs are mainly in the tectonic basement involvement and the effect of the shortening on the former rift basins. Both Bogor and Kendeng Troughs contain active petroleum systems with Type II /III kerogen typical of reducing environments organic material derived from transitional to shallow marine environments. The result suggests that these basins are separate from the neighboring basins with a "native" petroleum system specific to the palaeogeographical condition during the Paleogene to Neogene periods, whereas the North Java systems (e.g., Northwest and Northeast Java Basin) were characterized by oxidized terrigenous Type III Kerogen.

Keywords: Bogor Trough, Kendeng Trough, sub-volcanic, volcanic arc

\section{INTRODUCTION}

Java Island is a segment of the eastwest trending Sunda volcanic arc, which begins in Sumatra and ends in East Nusa Tenggara, and continues into the Banda arc (Figure 1). The arc and thus the island elongation orientation is parallel with the trend of the subduction zone. This volcanic arc formed since the Late Oligocene due to the orthogonal subduction of the IndoAustralian beneath the Eurasian Plate (e.g., Katili, 1973; Katili, 1975; Hamilton, 1979; Hall, 1996; Smyth et al., 2005; Pubellier and Morley, 2013; Metcalfe, 2017; van Gorsel, 2018). In general, the volcanic arc consists of several episodes of volcanism that become sequentially younger northward (from Late Oligocene to Pleistocene), following northward movement and subduction of the Indian Ocean-Australian plates. This movement is also believed to create subsequent northward thrusting and

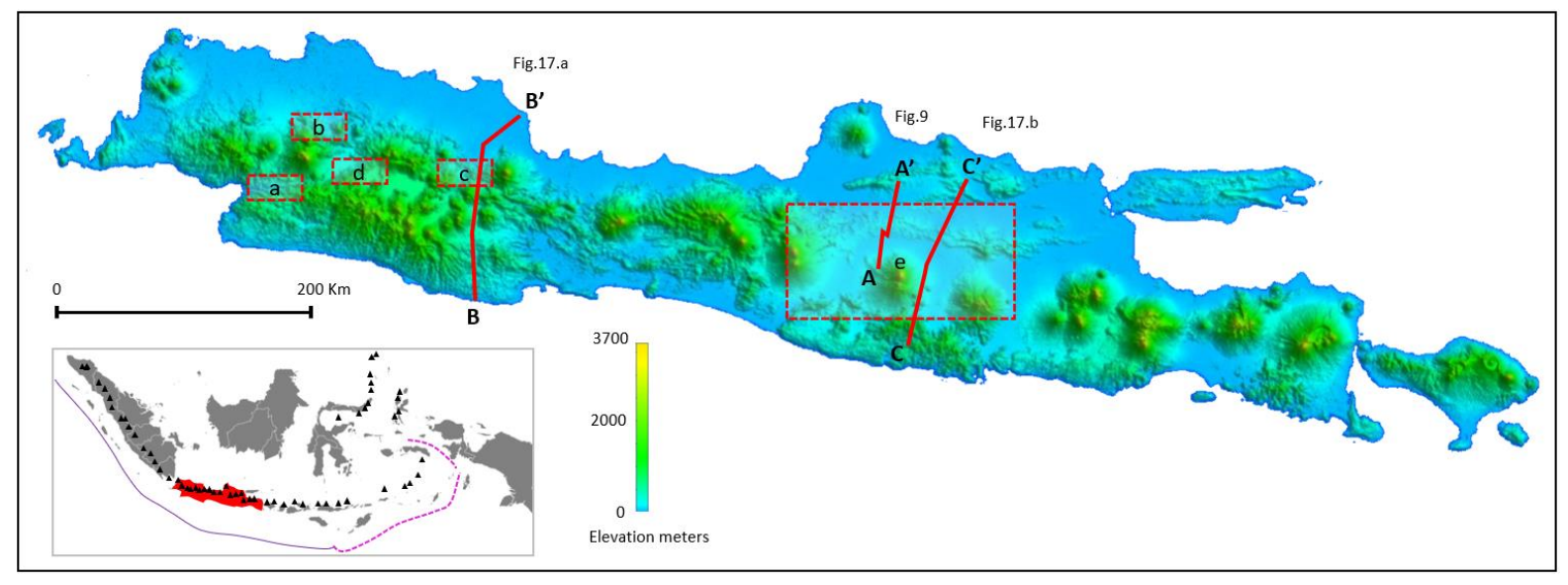

Figure 1. One arc second resolution shaded relief SRTM map of Java Island shows a cluster of active volcanoes and immense volcanic material covers over the study area in (a) Sukabumi, (b) Bogor, (c) Majalengka West Java, (d) Rajamandala, and (e) Kendeng zone Central and East Java. The index map shows the main volcanoes chain (black triangle) and Java Island (red) in respect to Sunda Arc (solid blue lines) and adjacent Banda Arc (purple dashed lines). Line A-A' is the gravity and seismic section in Fig. 9, lines $B$ - $B$ ' and C-C' are interpreted regional geological section in Fig. 17a. and Fig. $17 b$. 
folding of the volcanic arc (Clement et al., 2009) that explicitly affects the structural style in the study area.

The basin development of the east-west trending depression in the central axis of Java (from Bogor to Kendeng Troughs) is not so well understood, in contrast with the NW and $\mathrm{NE}$ Java Basins in the coastal plain and adjacent offshore along the Northern edges of Java Island, which are well known and wellstudied. A major challenge is seismic imaging, due to the structural complexity of the over thrusted shallow Neogene stratigraphic units, as well as the thick Quaternary volcanic cover. These deposits form an acoustic masking that makes imaging of the underlying basin configuration almost impossible.

Common oil and gas seepages are present around the northern and central parts of the island (Doust and Noble, 2008; Satyana, 2014; Doust, 2017), some of which are reported to produce quite voluminous hydrocarbons, confirming active petroleum generation in the area. Although the exact petroleum sources are unknown, this phenomenon led to the hypothesis that petroleum generation is likely derived from

Paleogene stratigraphic units underneath the volcanic covers. The hydrocarbons were expelled and transferred through the southerly dipping thrust fault or via e volcanic dyke remnant pathways (Satyana, 2014). This paper will mainly discuss prospect generation in the poorly understood Java volcanic arc frontier area.

\section{REGIONAL STRATIGRAPHY}

As the flexural margin of Bogor and Kendeng Troughs formed later in the Early Miocene, for the general purposes to denote the depositional history ranging from Paleogene to Neogene, we use the terminology of Bogor zone and 


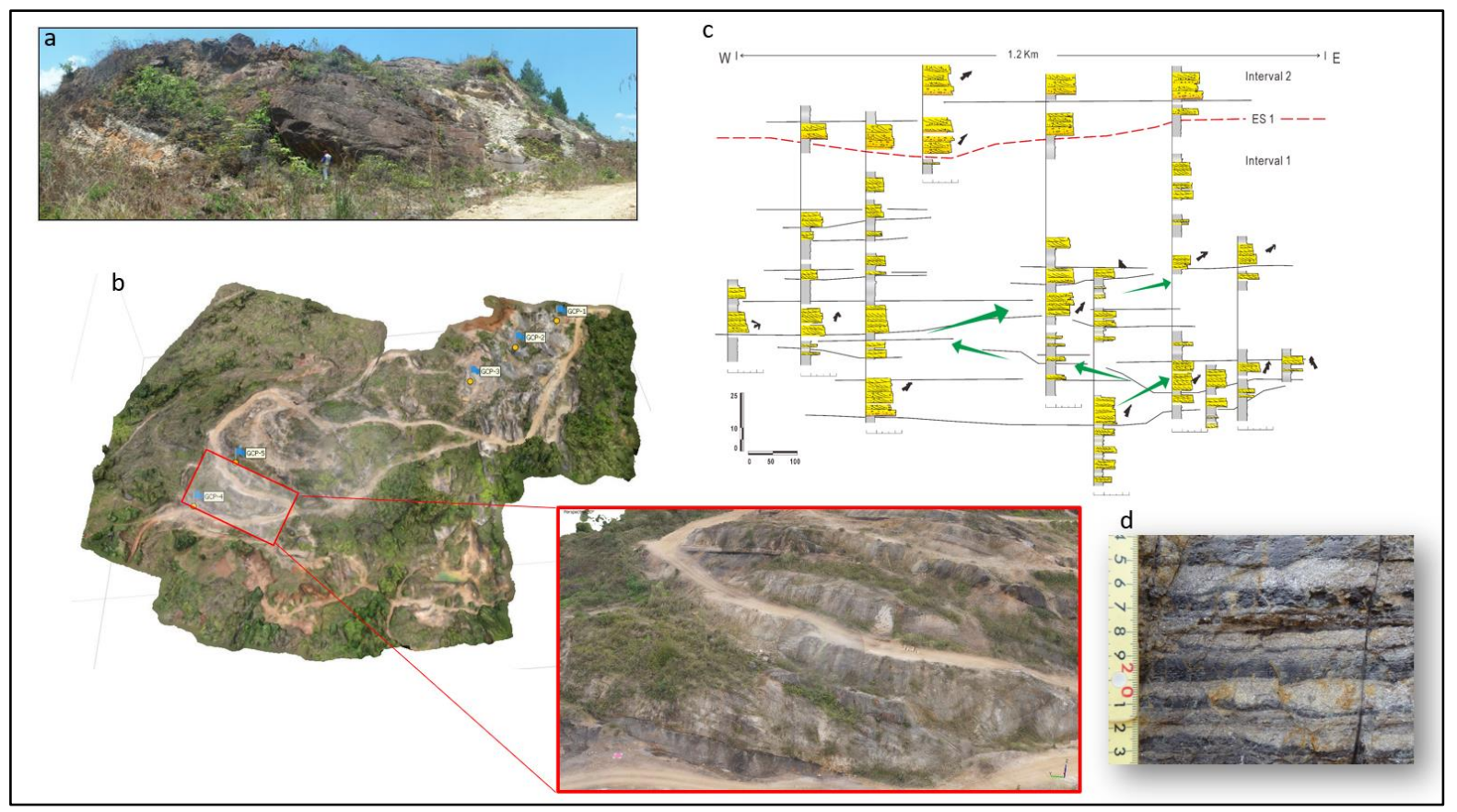

Figure 3. The Bayah Fm. outcrop in the Cibadak and Sukabumi High area shows stacking of Paleogene (Eocene to early Oligocene) fluvial channels with a total thickness of 915 meters. a) the most upper part of the fluvial unit shows a typical single channel story with a thickness of 9-11 meters. b) The digital outcrop models (DOM) of the fluvial sand exposure in the Kadupugur quarry area, near Cisaat with the inset taken parallel to the bedding, shows a lateral accretion package (LAP) with the paleocurrent direction toward the southwest. c) the interpretative measured section log correlation in Sekarwangi outcrop showing the channel migration evolution mainly toward south-southwest and few to south southeast direction suggests the major fluvial flow direction southward. d) The interbedded shale with a typical lacustrine deposit character. This shale unit contains abundant freshwater algae (see also Figure 4) and has a high total organic carbon content (Adhiperdana, 2018; UNPAD - Pertamina, 2020).

Kendeng zone. This section will focus on the stratigraphic succession in the Bogor and Kendeng zones compared to neighbouring basins or sub-basins (Figure 2).

The oldest rocks found in three complexes in the southern part of Java Island are Mesozoic metamorphic rocks, grading from phyllite to schist and gneiss. The age extracted from zircon dating from schist or eclogite ranged between 124-102 Ma in the Luk Ulo complex, $98 \mathrm{Ma}$ in the Jiwo Hills and 55-38 $\mathrm{Ma}$ in the Ciletuh area
(Satyana, 2014). These rock units are mostly buried and only exposed in limited areas such as Bayat, Karang Sambung, Bayah, and Ciletuh and are overlain by Paleogene or Neogene deposits elsewhere.

\section{West Java}

During the Eocene epoch, the West Java area was dominated by fluviolacustrine to the fluvio-deltaic depositional system of the ageequivalent Bayah and Walat Formations (Fm.). The Bayah Fm. is 


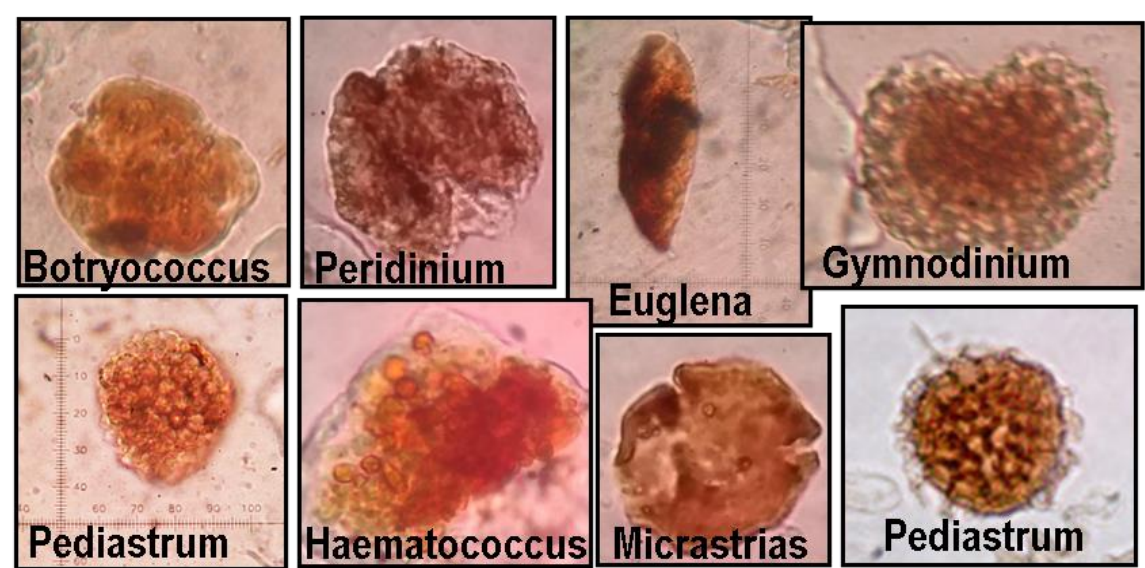

Figure 4. The freshwater algae from Eocene Bayah Fm. shale suggest periods of lacustrine deposition occasionally occurred during the fluvial deposition period (UNPAD - Pertamina, 2020).

In the upper interval, the Bayah Fm. was capped with transgressive shale and marl of the Batuasih Fm. which is dominated by calcareous mud with locally interbedded clastic and patchy limestone. This formation has marked the end of the terrestrial depositional period

found in several localities in the Sukabumi high area and is dominated by quartz sandstone, barren in marine fossils with some occurrences of spores and pollen, indicating a Late Eocene age in the lower part from palynological zonation of $M$. nayarkotensis, $P$. operculatus and P. kutchensis (Morley, 2012) and Early Oligocene from $F$. trilobata, M. medius and $V$. usmensis (Baumann et al., 1973; Martodjojo, 1984) in the upper part. The outcrops in the Cibadak area, Sukabumi reveal a stack of the thick fluvial deposits of up to 915 meters thick, with a significant paleo-current direction toward SouthSouthwest and Southeast suggest the deposition of the major fluvial system from North to South (Adhiperdana, 2018) (Figure 3a-d). Some intra-fluvial successions show a typical lacustrine character with layered shale units (Figure 3d) containing many freshwater algae such as Botryococcus, Peridinium, Pediastrum, Haematococcus, Euglena, and Gymnodinium (Figure 4). The interbedded fine-grained units in this formation also contain organic-rich coaly beds and shales units. of Bayah Fm., which was dated around nannoplankton zone CP18 and planktonic foraminifera zone P19 (within Early Oligocene) (UNPADPertamina, 2020).

The Rajamandala Fm. limestone growth in the Late Oligocene generally consists of two major depositional sequences, namely layered pack stone to boundstone with a local reef mound in the lower interval, which gradually changes upward into deeper marine facies of marl and calcilutite. This formation becomes deeper northward (Koesoemadinata and Siregar, 1984), likely controlled by the paleo-high configuration during the reef growth. The benthic foraminifera analysis indicates that this formation is deposited in inner to middle neritic environments (e.g., Irwansyah et al., 2011; Sekti, et al., 2011; Wibowo and Kapid, 2014; Gani et al., 2020).

\section{Central and East Java}

Rapid subsidence marked the Neogene period in the middle of Java Island. The 

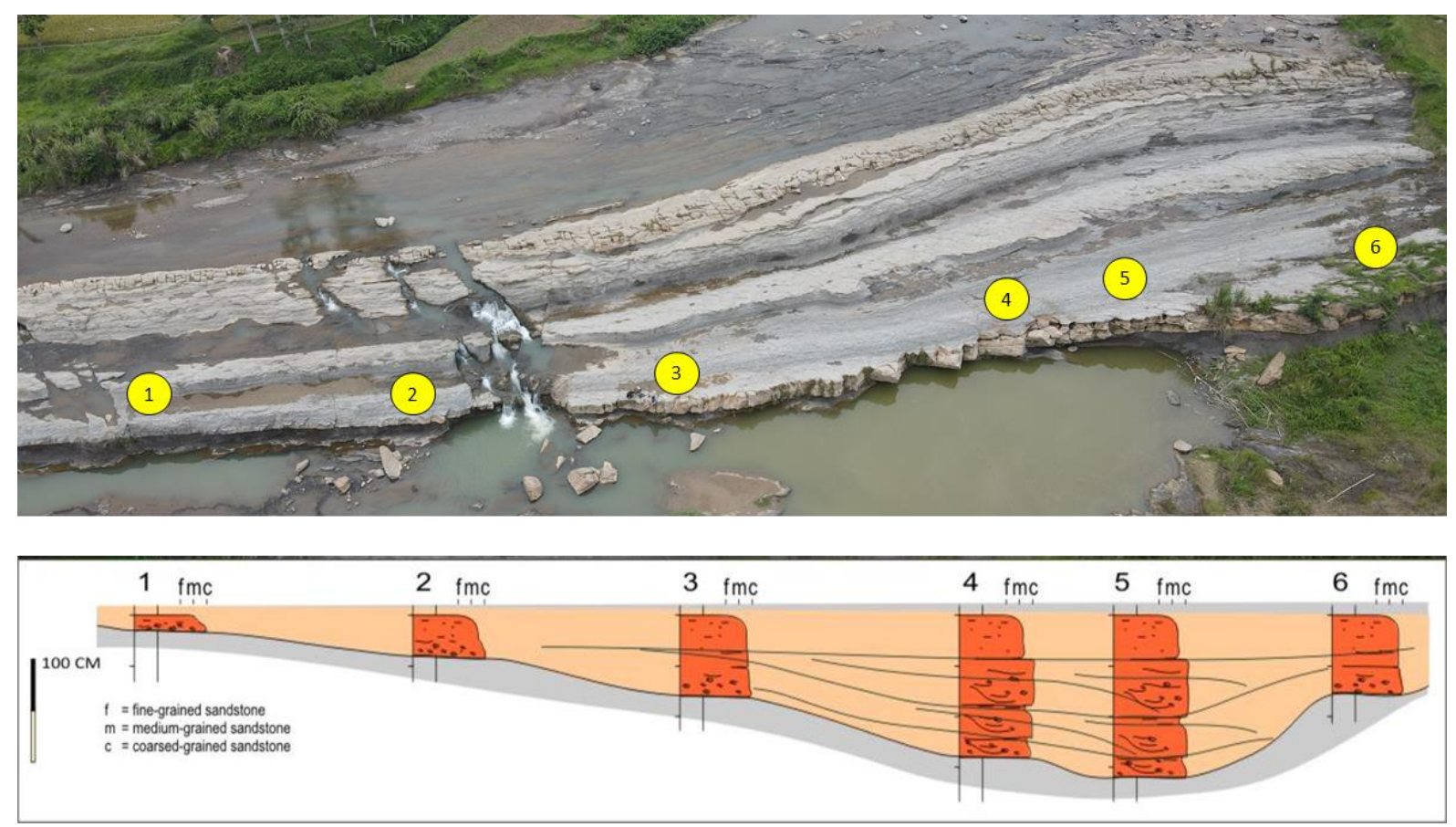

Figure 5. The drone photograph of the deep-water deposit in Jatiluhur Fm. in Cipamingkis River shows blocky and sheet-shaped characters consistent with Bouma turbidite sequence Ta and Th. The deposit was 70 meters long and showed a wedge out termination leftward (Southwest direction). This outcrop was interpreted as a coarse-grained slump scar deposit. (Abdurrokhim, 2017; UNPAD - Pertamina, 2020).

trough deepening was initiated during the early Miocene and was followed by the deposition of deep-sea sediments including the volcaniclastic-rich Jampang Fm. and Citarum Fm. in the Sukabumi high and Bandung areas, then continued by Jatiluhur Fm. in the Bogor area and the Cinambo Fm. in the Majalengka area (Muljana et al., 2012) (Figure 5). The volcaniclastic rich materials show the possible mixed provenance from the older volcanic arc in the Southern Mountains area (Hall and Smyth, 2008; Waltham et al., 2008; Seubert, 2015). The succession gradually changes to the relatively shallow marine environment upward where the limestone of Klapanunggal Fm. developed. The rock unit consisted of coral boundstone and rudstone, skeletal rich grainstone, and locally interbedded wackestone and packstone layer (Abdurrokhim, 2017). This formation growth was taking place in Late Miocene (Martodjojo, 2003).

The Paleogene unit interval was absent, and the occurrence of them in the Kendeng zone surface area remained a mystery. The oldest exposed outcrop accessible for this study is Early to Middle Miocene neritic to upper bathyal Pelang Fm. which consisted of interbedded marl and calcareous sandstone. This formation is only exposed in a limited area at the Juwangi, Pelang River, and surrounding area. The thick marls with a thin bed of calcareous globigerinidrich sand were found in the Juwangi area and interpreted as shallow marine deposits with a local internalite deposits bed (e.g., in Warren, 2018) (Figure 6a-f). The oldest planktonic 
Foraminifera zonation using G. kugleri as index fossil and shows an age of N3N5 (Late Oligocene to Early Miocene). The depositional environment was predicted as lower neritic to upper bathyal environmental.

The mud-volcano ejects material in one location in Sangiran Dome, Surakarta, shows the strong evidence that the older Paleogene sediment exists below the Pelang Fm. The hand specimen observation shows that the ejected rocks had a similar characteristic with
Nanggulan and Bayat Fm. Clastic carbonate with Eocene large foraminifera including Nummulites like those exposed in the Bayat area is present, together with other older rocks such as conglomerate and metamorphic rock. Although this older unit's existence and configuration in the subsurface are questionable, hypothetically, these Paleogene units were believed to be distributed widely in the lower stratigraphic interval in the Kendeng area.

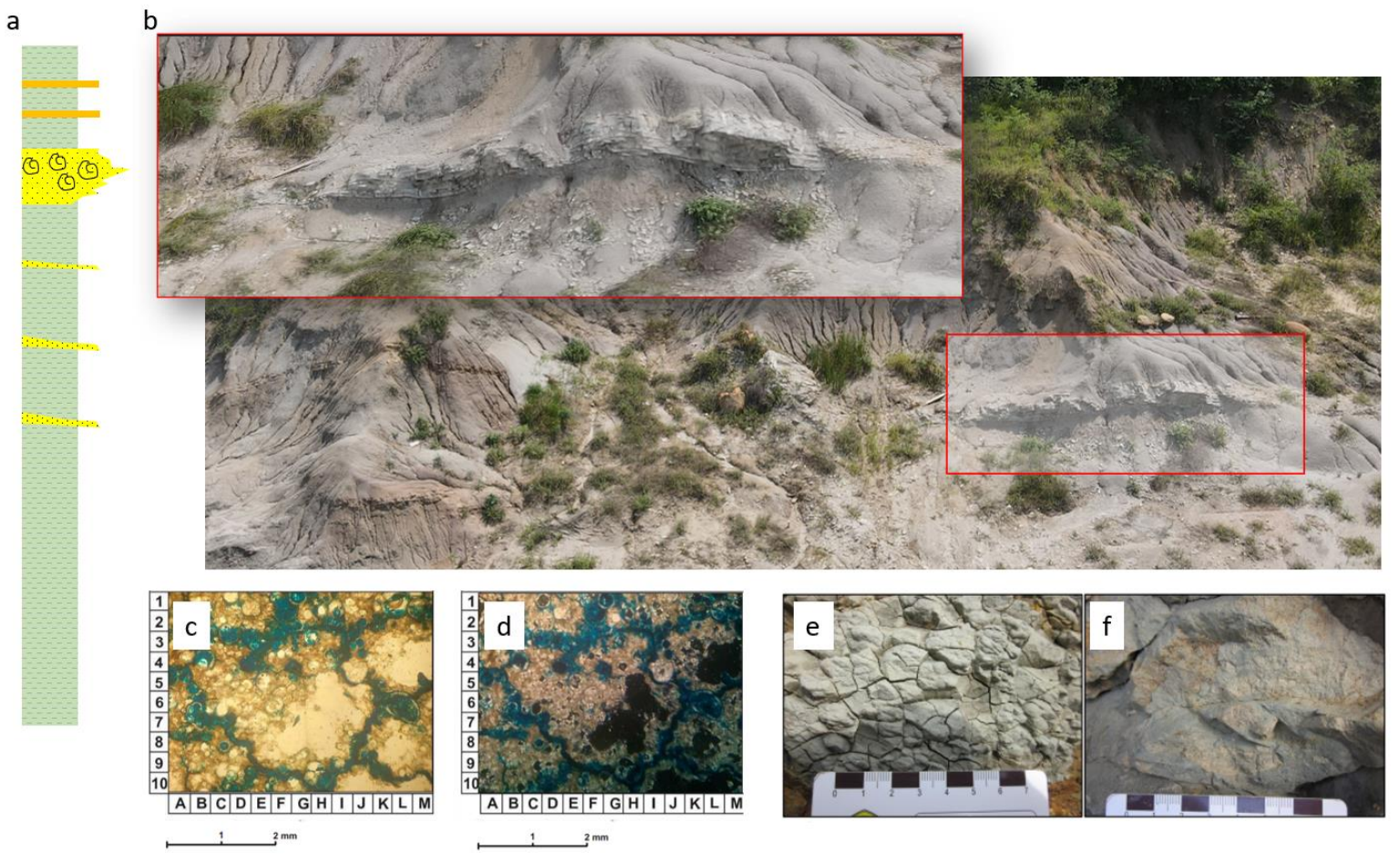

Figure 6. The Early to Late Miocene Pelang Fm. shows a thick structureless mudstone and marl layer; in the upper section, the thin laminae of evaporite deposit (anhydrite) were found and interpreted as sequence boundary where this unit was once exposed sub-aerially (a). b) the digital outcrop model (DOM) of the outcrop near the provincial road in the Juwangi area, the outcrop length is 70 meters with a total thickness of 20 meters. The inset shows that the globigerinid sand layer in the lower right image is 1.5 to 2 meters thick. The sand layers show a paleocurrent with southeastward direction c) the parallel nicol and d) cross nicol of the photomicrograph of the globigerinid sand layer shows a relatively southeast oriented of the fossil grains interpreted to be formed in the high energy regime such as tidal channel or perhaps internalite deposits? (e.g., in Warren, 2018) e) the marl specimen shows the structureless character with some burrows. f) the globigerinid sand specimen could be classified as packstone. 

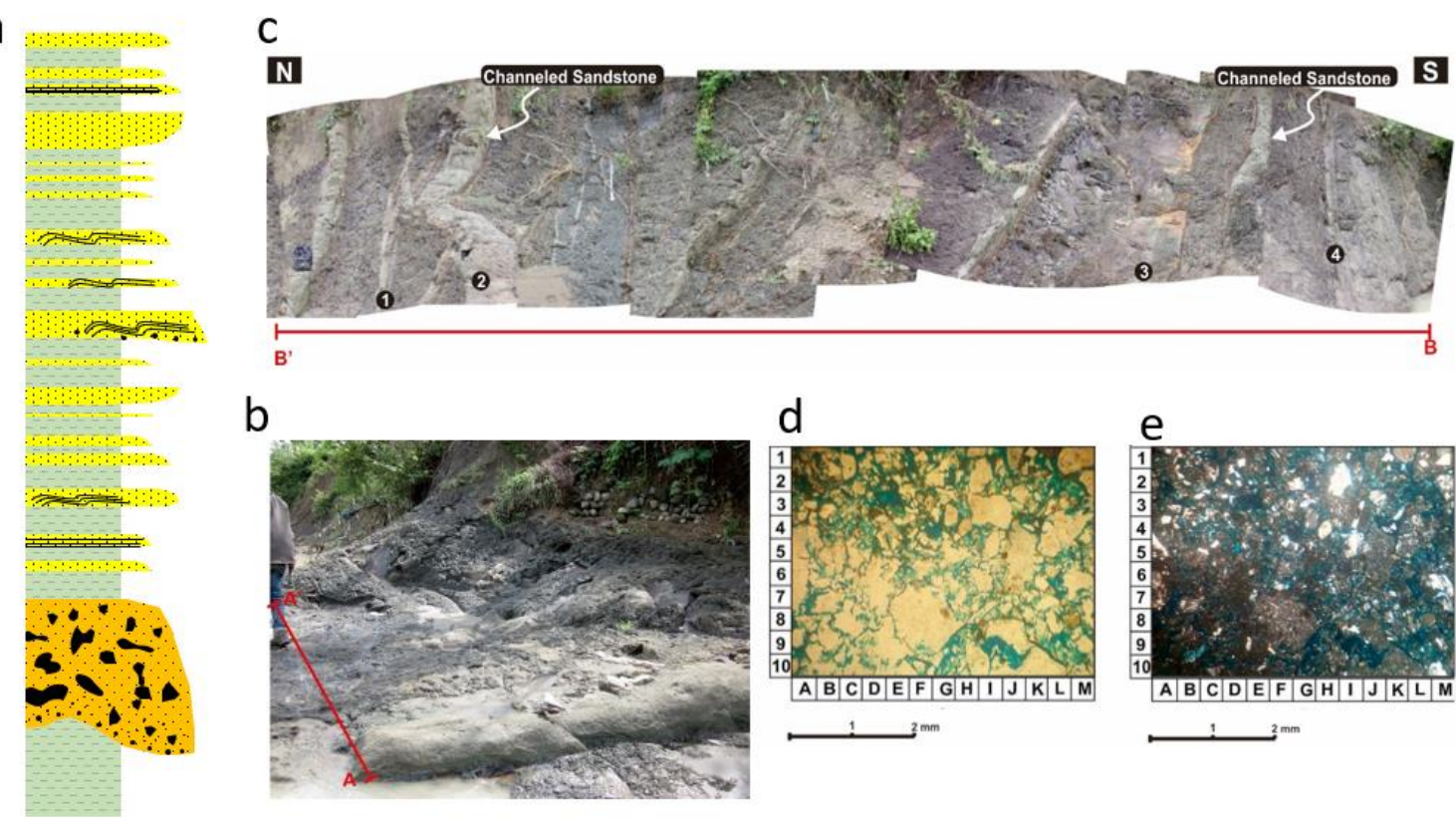

b

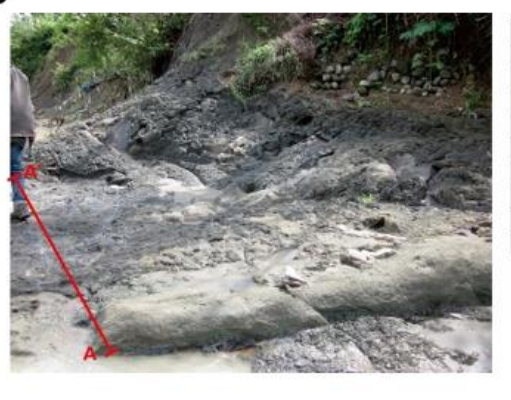

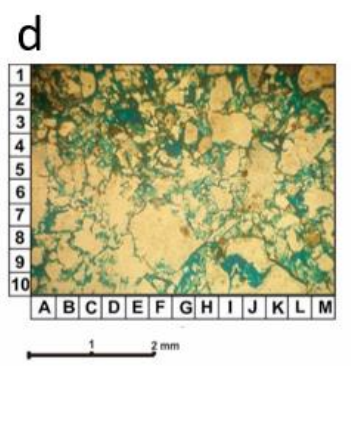

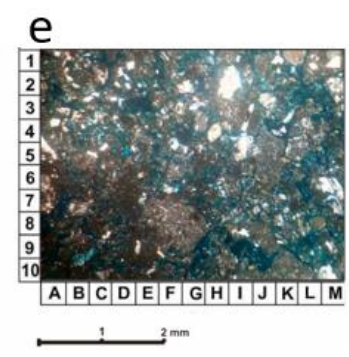

Figure 7. The middle Miocene Kerek Fm. shows alternating sandstone and shale layers. The measured stratigraphic logs (a) showing an interbedded debris flow deposit in the lower part of the section with a coarse fragment (boulder to pebbles size) deposit as an initial stage sequence, e.g., as a traction carpet in the base of deposition (b). c) The upper section showing a classic Bouma turbidite sequence Ta to Tc coarse to fine-grained sand layer $(20-40 \mathrm{~cm}$ in thick). d) the parallel and e) cross nicol photomicrograph showing a mixed provenance between quartz and volcaniclastic materials suggest the multi-directional provenance from the north (Sundaland) and south (southern mountain range).

The carbonate development is intensified in most areas during the transgression periods in Oligocene to early Miocene, followed by the rapid depositional of the deep-sea sediment of Kerek Fm. to Kendeng Trough during a short period in the middle Miocene. The volcaniclastic rich materials confirmed the possible mixed provenance between the quartz arenite dominant provenance from the sundaland continental margin and the lithic and volcanic rich provenance from Southern Mountains area (Hall and Smyth, 2008; Waltham et al., 2008; Seubert, 2015). The Kerek Fm. consists of interbedded shales and sandstones with some locally calcareous shale layer and conglomeratic layer shows a classical turbidite succession consistent with Bouma sequence Ta-Tc (Figure 7a-e). This formation age is around N13 - N20 or Middle Miocene to Early Pliocene. stratigraphic succession gradually changes to the shallower marine environment upward in Late Pliocene with Klitik and Kapung limestone member in the Kendeng Trough. The formation consists of interbedded mudstone, marl, and calcareous sandstone.

In contrast to the Bogor and Kendeng areas, during the early to middle Miocene, the NW and NE Java Basins became part of a stable shallow shelf area with the deposition of Cibulakan and Parigi Formations in the west and a succession of thick carbonate growth such as Tawun, Bulu, and Ngrayong in 


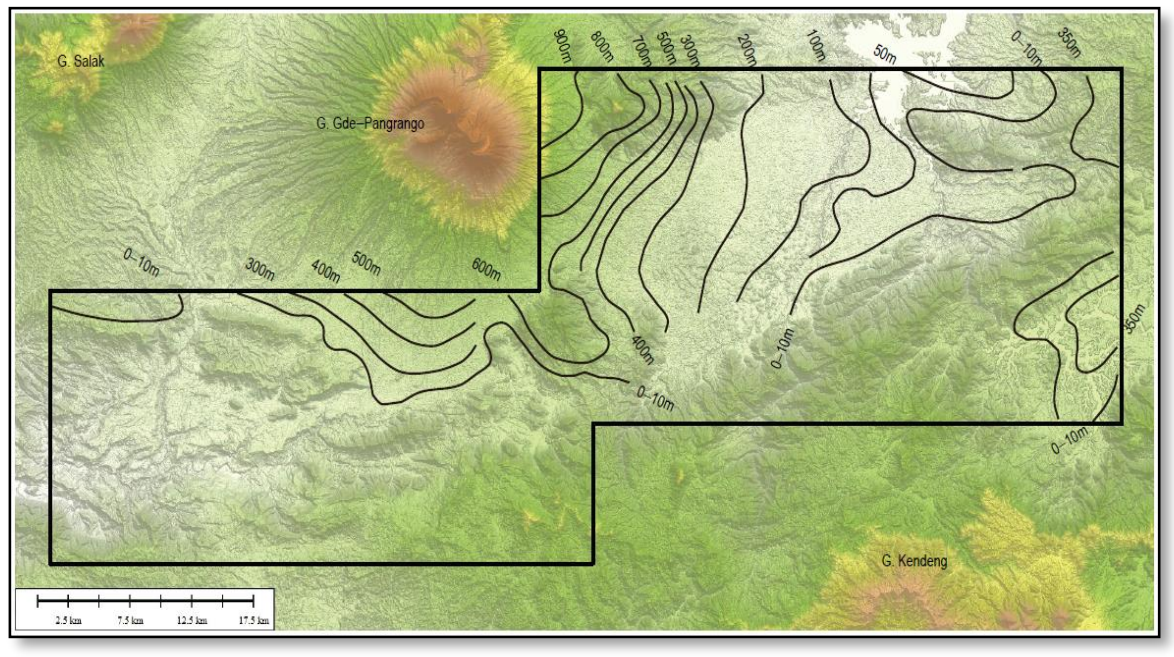

Figure 8. The extrapolated volcanic covers map is estimated from various data collection such as topographic data, direct outcrop measurement, and water well data, for example, from Mt. GedePangrango foothill, Sukabumi area, contour interval: 100 meters (UNPAD-Pertamina, 2020).

the NE Java Basin (Simo, 2011; Lunt, 2013; Lunt, 2019).

\section{DATA AND METHODS}

Our research study integrated the surface geology sampling and measurement, exploratory subsurface data, geochemical analysis, basin modelling, newly acquired field gravity, magnetic data, and previously available gravity and magnetic data. Four (4) research window areas in West Java and one large extent research window in Central-East Java have been selected. A total of $1,893 \mathrm{~km}$ measuring sections, 584 rock samples (petrography, micropaleontology, and reservoir rock characterization), 201 stations gravity data, 269 stations magnetic data, and 29 geochemical samples (source rock pyrolysis, oil and gas chromatography, and gas isotope) were acquired during the study. The preserved paleo-current in several exposures (e.g., Bayah Fm., Kerek Fm.,
Jatiluhur, and Cinambo Fm.) were used to identify the main flow direction, dispersal pattern, geometry, and paleogeographic condition during the deposition period.

The volcanic covers were estimated and measured from compiled data collection such as topographic map, direct measurement in outcrop, or the report from water well rock description in the surrounding urbanized area in the west of study area (UNPAD-Pertamina report, 2020) (Figure 8).

The horizontal and vertical gradient/derivative analysis was performed on field gravity data to clarify the boundary of the sources signal, whether it is caused by a structural boundary (low frequency) or internal basin configuration (high frequency) in Kendeng Trough. The 2.5D geomagnetic modelling was performed by integrating field observation data, surface geology information, fold-thrust conceptual model. The block model construction iterative by trial and error considers the variation of misfit between observed vs. calculated data.

The old exploratory wells and seismic section were used for reference. Geological fieldwork was focused on the 
stratigraphic unit composition and the observable features of deformation products from the outcrops. We used biostratigraphy, petrography, and paleocurrent analysis to verify the stratigraphy framework's consistency. Due to the Paleogene deposit exposure scarcity in the Central-East Java area, the rock samples were also collected from the mud volcano ejecta materials area for advanced study. Due to the subsurface geochemical data limitation, where there are only two wells available (Toto- 1 and Ngawi-1 in East Java area), some parameters such as TOC, HI and Ro are extracted from surface geochemical samples and calibrated to the designated generation depth.

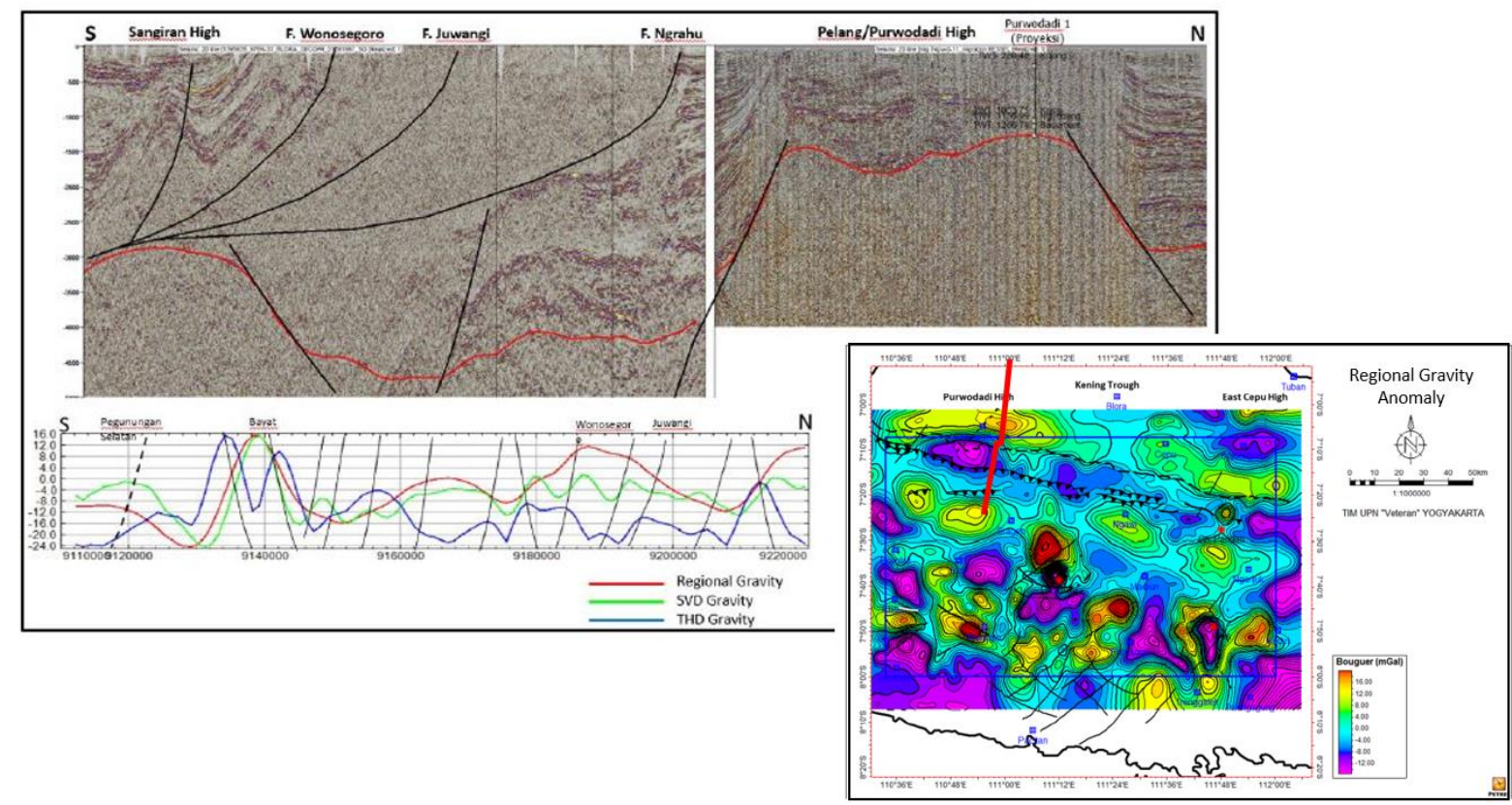

Figure 9. The surface geological measurement integrates seismic data and existing and newly acquired gravity and magnetic data to reconstruct the basin configuration models in Kendeng Trough, Central - East Java. Index map shows the most updated (2020) regional gravity anomaly data (UPNY-Pertamina, 2020). The red square is the seismic coverage area. See Fig. 1 for the location.

in the Sangiran Dome area. The comprehensive surface and subsurface data integration are expected to conceal the inferred volcanic covers, structural styles, and sub-basin configurations model (Figure 9).

Furthermore, this model will be used to reconstruct the regional palinspastic section (Figure 10). The $1 \mathrm{D}$ and 2D basin modelling approach was used to localize the most favorable prospect

\section{RESULTS AND DISCUSSION}

\section{Field Geology and Structural Reconstruction}

Bogor Trough: The stratigraphic succession is characterized by a very thick (up to $1000 \mathrm{~m}$ in outcrops) transgressive sequence from Bayah Formation (Fm.) fluvial deposits in the lower part overlain by conformable paralic deposits of Batuasih Fm. and 
carbonates facies of Rajamandala Formation.

Bayah Fm. consists of thin to very thick-bedded coarse-grained sandstone, mudstone, and carbonaceous mudstone layers. Some organic matters contain freshwater algae and wooden fragments. Those Paleogene deposits were overlain by a very thick Neogene Volcanoclastic deepwater succession with southward and northward paleocurrent directions indicating multi-directional sedimentation. This process possibly resulted from a big tectonic uplift event that might be responsible for creating the flexural trough and the peripheral paleo-high area (Figure 10).

Kendeng Trough: Contrary to the West Java area, the Paleogene stratigraphic unit was absent in outcrops. They could only be found scarcely outside the study windows (e.g., Karang Sambung, Bayat, and Nanggulan).

The oldest stratigraphic unit found in this study window is Pelang Fm. that consists of marl and alternating thin laminae of calcareous sand. The upper section shows a widespread thick deepsea depositional system of Kerek Fm. consisting of volcanic rich medium to fine-grained sandstone bed alternating with silt and shale. The Kalibeng Fm. is deposited with a dominant marl and shale deposition on the top section with intercalated limestone of Kapung and Klitik Member.

Structural reconstruction: Bogor and Kendeng Troughs' significant differences are in the basement and

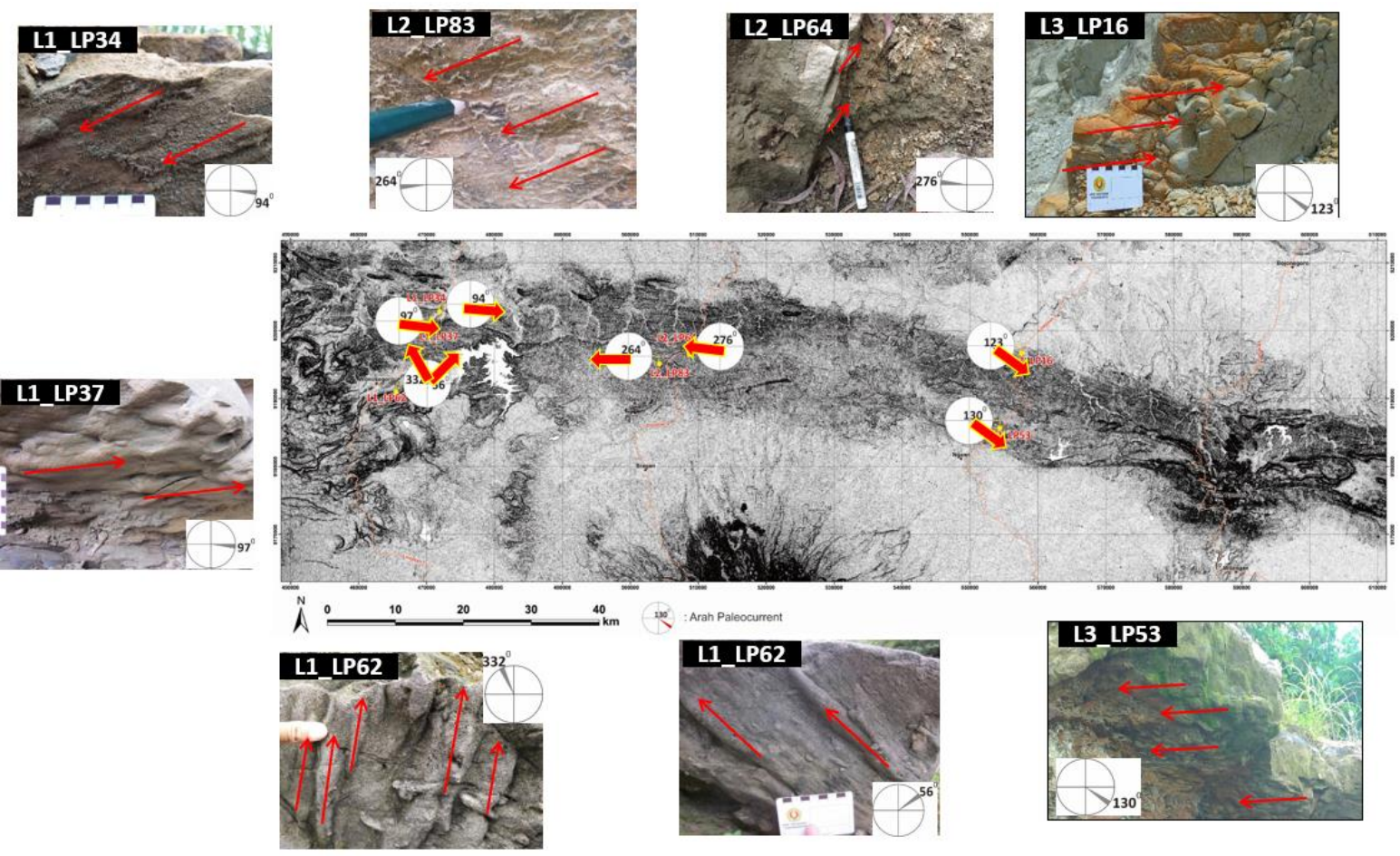

Figure 10. The paleo-current measurements in the Kerek Formation, Kendeng Trough, shows a multi-directional sediment source that suggests the pre-existing topography during Kendeng Trough deposition in Middle Miocene. 

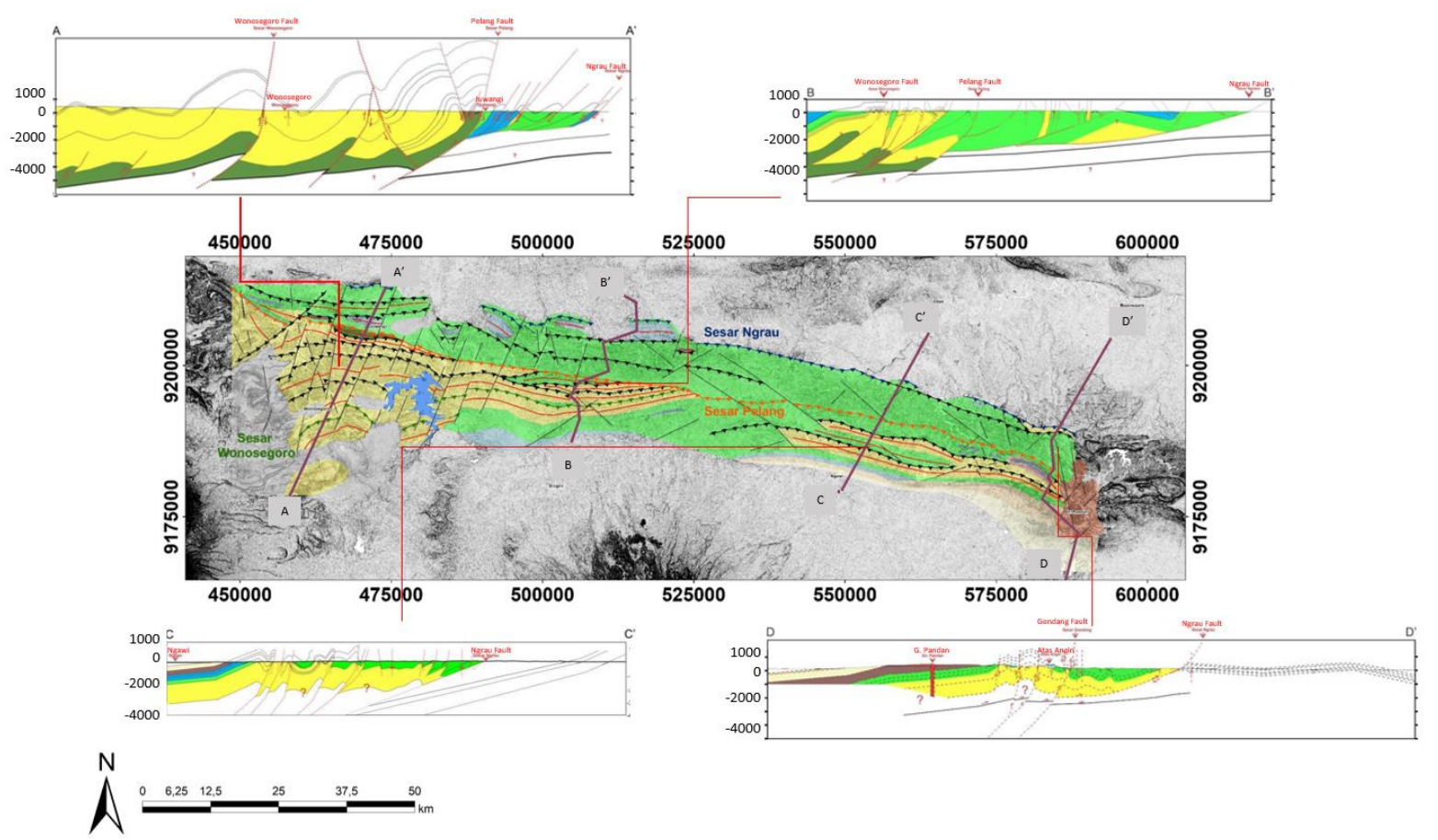

Figure 11. The structural reconstruction in Kendeng area based on surface geological data measurement combined with the subsurface integration of gravity, magnetic and regional seismic data (UPNY-Pertamina, 2020), grey: volcanic covered area, dark green: Pelang Fm, yellow: Kerek Fm., light green: Kalibeng Fm. and teal: Klitik Fm.

Paleogene unit thrusting involvement. The palinspastic reconstruction shows that the sediment unit in the West Java section is more intensively shortened than the East Java section. The rifting followed by the thrusting phase is common and observed throughout the southern and central median of Java Island (Satyana and Purwaningsih, 2003; Yulianto et al., 2007; Satyana, 2016). The structural observation and reconstruction in Bogor Trough demonstrate the semi thin-skinned model where the basement act as a decollement and thrusting has overprint the initial rifting phase especially in the northern part, adjacent to the deep-water margin, thus forms an inseparable structure configuration. Kendeng Trough, on the contrary, shows an opposing thickskinned geometry model with an involved basement fold-thrust belt and shows the remaining rifting phase remnants with thrust sediment packages above it (Figure 11 and 17).

\section{Geochemical Analysis and Basin Modelling}

The oil and gas seeps in the northern and median part of Java Island suggest the hidden active petroleum system underneath the volcanic covers. The hydrocarbon seepages are manifested to the surface from the middle of the depocenter, likely via the conduit from southerly dipping thrust or volcanic intrusions. The organic richness, oxygen index, and maturity plot versus the hydrogen index suggest that most of the samples taken in Bogor or Kendeng Troughs are derived from Type II/III kerogen suggesting the terrestrial transition source rock origin. 

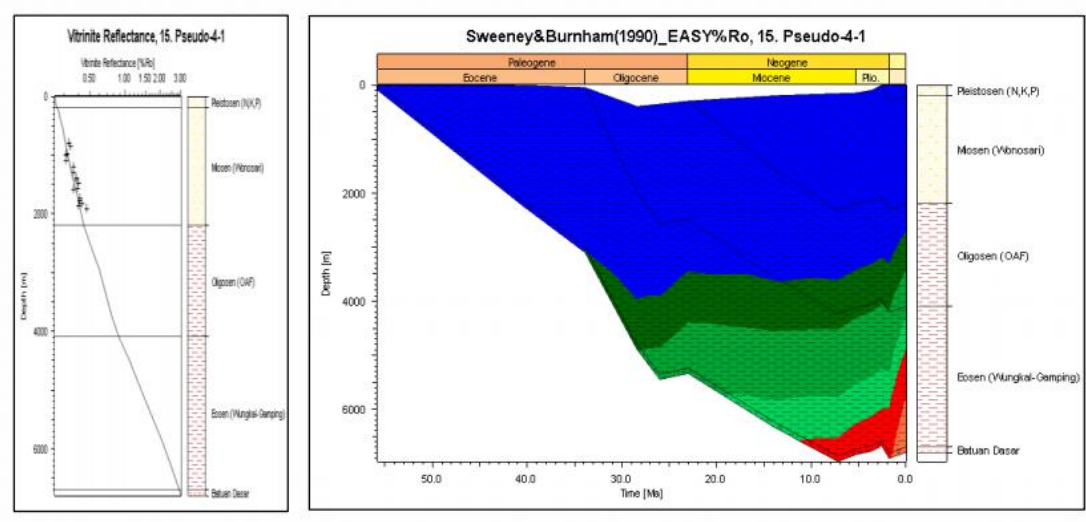

Figure 12. The geochemical modelling in Kendeng Trough; see text for the explanation. Color legend: blue: immature (0.000.55), dark green: early oil (0.55-0.7), green: main oil (0.7-1.00) Light green: late oil (1.00-1.3), red: wet gas (1.30-2.00), orange: dry gas (2.00-4.00).

The source rocks pyrolysis data from Bogor Trough (Bayah Fm., Batuasih Fm., and Cinambo Fm.) shows a fair to good total organic content (TOC) of 0.9$2.7 \%$, low hydrogen index (HI) of 3-280 $\mathrm{mg} \mathrm{HC} / \mathrm{gr}$ TOC, indicating the ability of the petroleum system to generate gas. The Tmax value ranges between 429$476{ }^{\circ} \mathrm{C}$, suggests the immature to the early mature stage of hydrocarbon generation. A lower result was observed in Kendeng Trough (Pelang Fm.), where the TOC range is 0.22-0.72 \% (poor to fair), Tmax value between 259 $423^{\circ} \mathrm{C}$, and very low $\mathrm{HI}$ of $19-265$ mg HC/gr TOC. This suggests that the hydrocarbon should have come from older unit than the Pelang Fm. The maturity analysis from both Bogor and
Kendeng

Troughs indicates that the hydrocarbon most likely were derived from Eocene stratigraphic unit eq. Bayah Fm. in Bogor Trough and eq. Wungkal-Gamping or Nanggulan Fm. The basin modelling in Kendeng Trough suggests that the early oil generations ranged between 29-22 Ma (Late Oligocene to Early Miocene) and then reached the peak oil generation in approximately 14.5-10 Ma (Middle Miocene) and gas generation in 2-1.5 Ma (Pleistocene) (Figure 12).

\section{Bogor and Kendeng Trough vs NW and NE Java Basin Source Rocks}

The source rock pyrolysis and oil and gas chromatograph from both Bogor and Kendeng Troughs indicates the kerogen Type II and III typical to
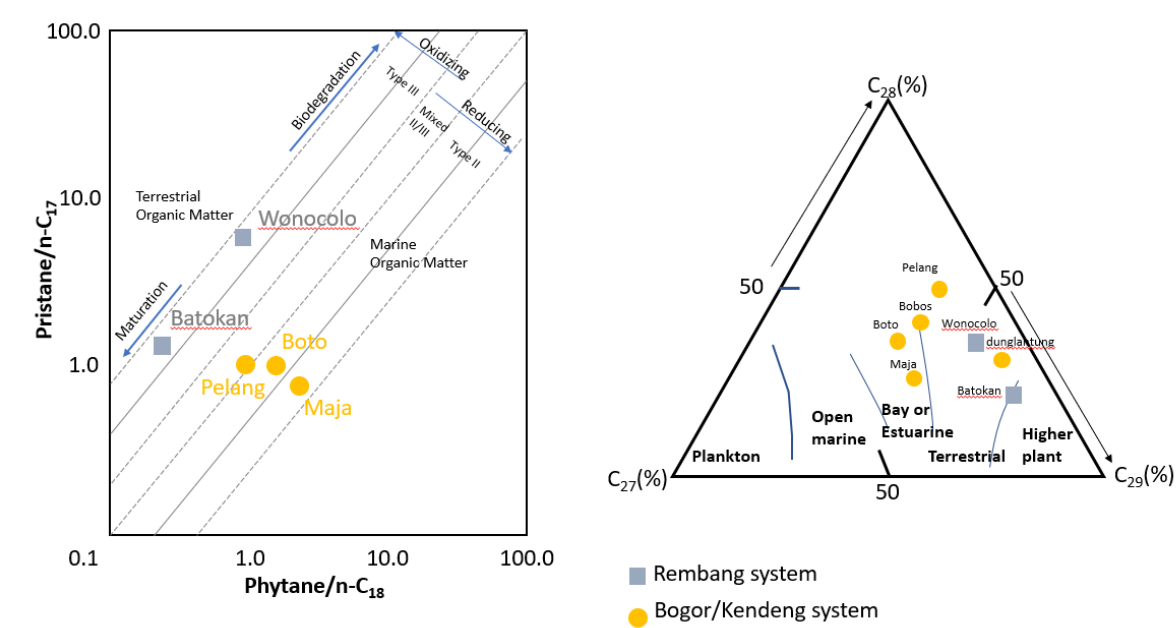

Figure 13. The $\mathrm{Pr} / n-\mathrm{C} 17$ vs $\mathrm{Ph} / n-\mathrm{C} 18$ plots (left) Huang and Meinschein plot of relative amounts of C27, C28 and C29 regular steranes in oil samples as an environmental indicator (right). 

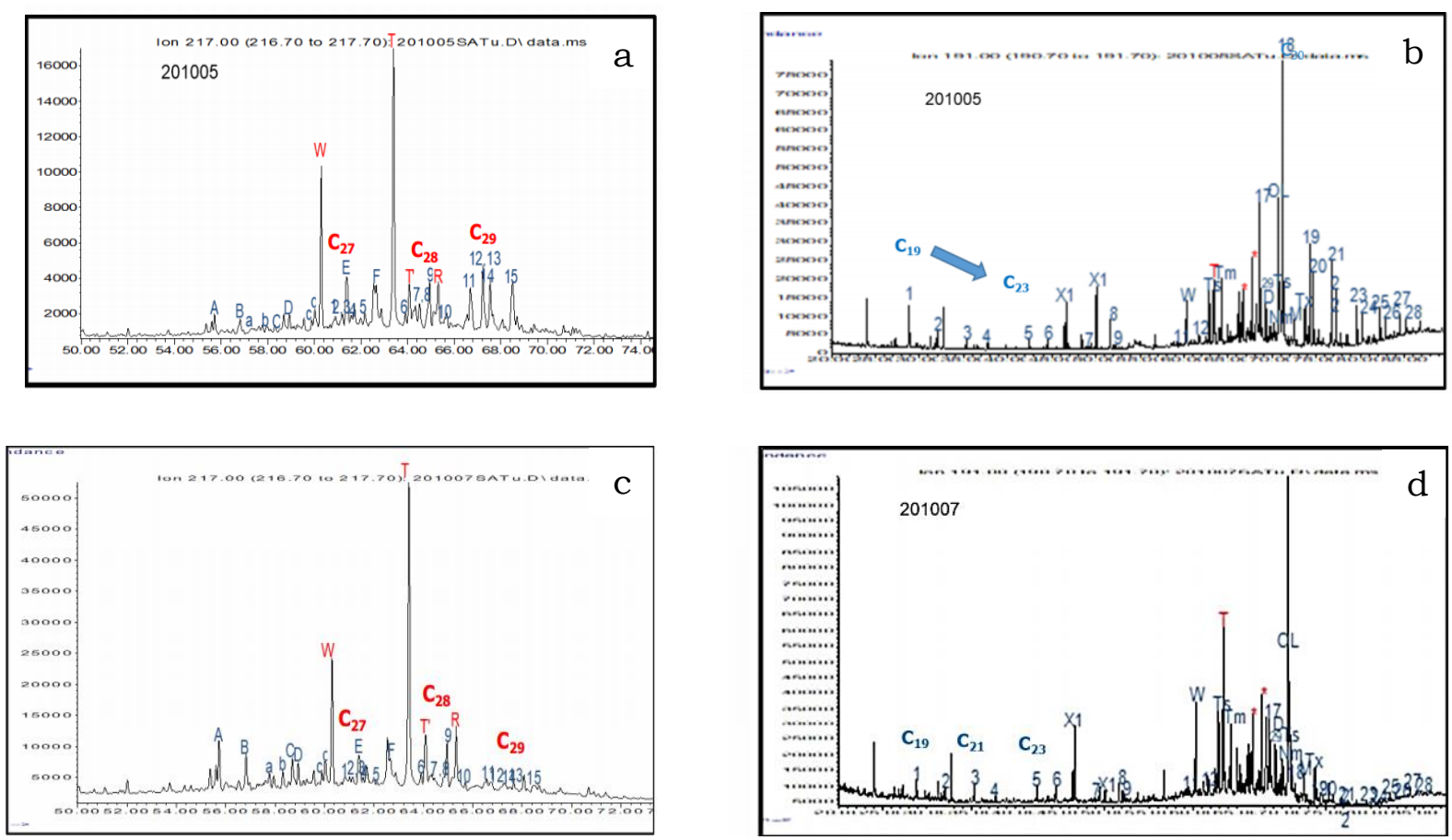

Figure 14. The comparison between sterane $\mathrm{m} / \mathrm{z} 217$ (left) and triterpane $\mathrm{m} / \mathrm{z} 191$ (right) fingerprints between Wonocolo well, Rembang zone (above), and Boto seepage, Kendeng Trough (below) (see text for the explanation).

transition or shallow marine environment. Sample from Boto oil seep (Kendeng zone) shows a high bicadinane with a balanced number of $\mathrm{C}_{27}$ vs $\mathrm{C}_{29}$ suggest the mixed of terrestrial and transition origin. The equal high of $\mathrm{C}_{19}, \mathrm{C}_{21}$, and $\mathrm{C}_{23}$ also suggest the strong marine influence (Peter and Moldowan, 1993), where the complete hopane family of $\mathrm{C}_{19}-\mathrm{C}_{35}$ exhibits the transition environment origin (Figures 13 and 14). The ternary plot of relative amounts of $\mathrm{C}_{27}, \mathrm{C}_{28}$, and $\mathrm{C}_{29}$ regular sterane in oil samples (Huang and Meinschein, 1979) also supports the above interpretation and suggests that the Kendeng and Bogor Troughs samples are plotted more to the transition depositional environment (Figure 13).

The above result is slightly different from the fingerprint gas chromatography from the Rembang zone, Northeast Java Basin. The chromatograph shows the n-Alkane peak in $\mathrm{C}_{19}$ presumably is dominated by freshwater algae organic matter. The cross plot between $\mathrm{Pr} / \mathrm{n}-\mathrm{C}_{17}$ vs $\mathrm{Ph} / \mathrm{n}$ $\mathrm{C}_{18}$ as an environmental and maturation indicator specifies the Type III Kerogen in a relatively oxidized environment, most likely terrestrial in origin (Figure 13). The gas isotope data shows that the NE Java samples are likely less mature if compared to the Kendeng and Bogor Trough samples. The chromatograph from Wonocolo well, although similarly high in bicadinane, likely shows a higher number of $\mathrm{C}_{29}$ with low diasterane, suggesting a terrestrial source origin with poor anoxic clay source rocks (Figure 14). 


\section{GROSS DEPOSITIONAL}

\section{ENVIRONMENT}

The hypothetical Gross Depositional Environment (GDE) model was reconstructed based on the integration of the available datasets and literature (Hall et al., 2007; Hall and Smyth, 2008; Lunt, 2013; Lunt, 2019,) with a specific focus area in the Bogor and Kendeng Troughs zones (Figure $15 \mathrm{a}-\mathrm{c}$ ). We subdivided the major palaeogeographical events into three (3) major stages: Eocene, Late Oligocene, and Middle Miocene.

\section{Eocene}

During the Eocene epoch, the Bogor zone and Northwest Java basin were one connected passive margin system of the south-southeast edge of Sundaland with the main sediment transport directions southward. This margin shows a deepening trend to the east, probably due to the remnant of the Cretaceous suture zone that creates a low depression area to the east. However, due to the data scarcity in the Central Java area, we skip the interpretation in the Banyumas area and adjust the condition to the nearest location of the West Java area. A terrestrial deposit dominated the depositional in the west area. The intensive phase of rifting during the

Eocene creates a sub-basin filled by synrift sediment, including a fan delta associated with a marine or lacustrine environment. The fluvio-lacustrine environment was developed with the major river flow orientation to the southwest. These river systems might be partially associated and controlled by the NW-SE-oriented block faulting. During this time, some local depression areas were collecting water and possibly become a localized lacustrine system. At the same time, the Eastern Java area was partly submerged. The Rembang area was established as a terrestrial to transition environment and produced thick deltaic and lacustrine deposits of the Ngimbang Fm. The Kendeng area was becoming a transition area as early as the Eocene epoch with the deposition of deltaic and tidal deposits associated with other shallow marine deposits. This depositional system is likely equivalent to Nanggulan and Wungkal Fm. This study also distinguished a local high area with east-west trending ridges from gravity and magnetic data. This ridge was christened as The Sangiran High, which continues eastward into a promontory shaped Ngawi High. This ridge separates North and South Sangiran Deeps; which is interpreted to have a continuity to $B-D$ ridges in Madura Strait (Sribudiyani et al., 2003; Prasetyadi et al., 2016) (Figure 15a).

\section{Late Oligocene}

In the Late Oligocene, a regional transgression was initiated, marked by the rapid marine sediment deposition in the eastern Java, producing a thick sequence of the limestone in NE Java and Rembang Basins such as Kujung and Prupuh Fm. and the initial deposition of Tuban Fm. Near the onshore area, Pelang Fm. consists mainly of the various shelf, and transition deposits developed. The limestone unit equivalent to Pelang Fm. was also believed to develop in the Sangiran paleo high area. 


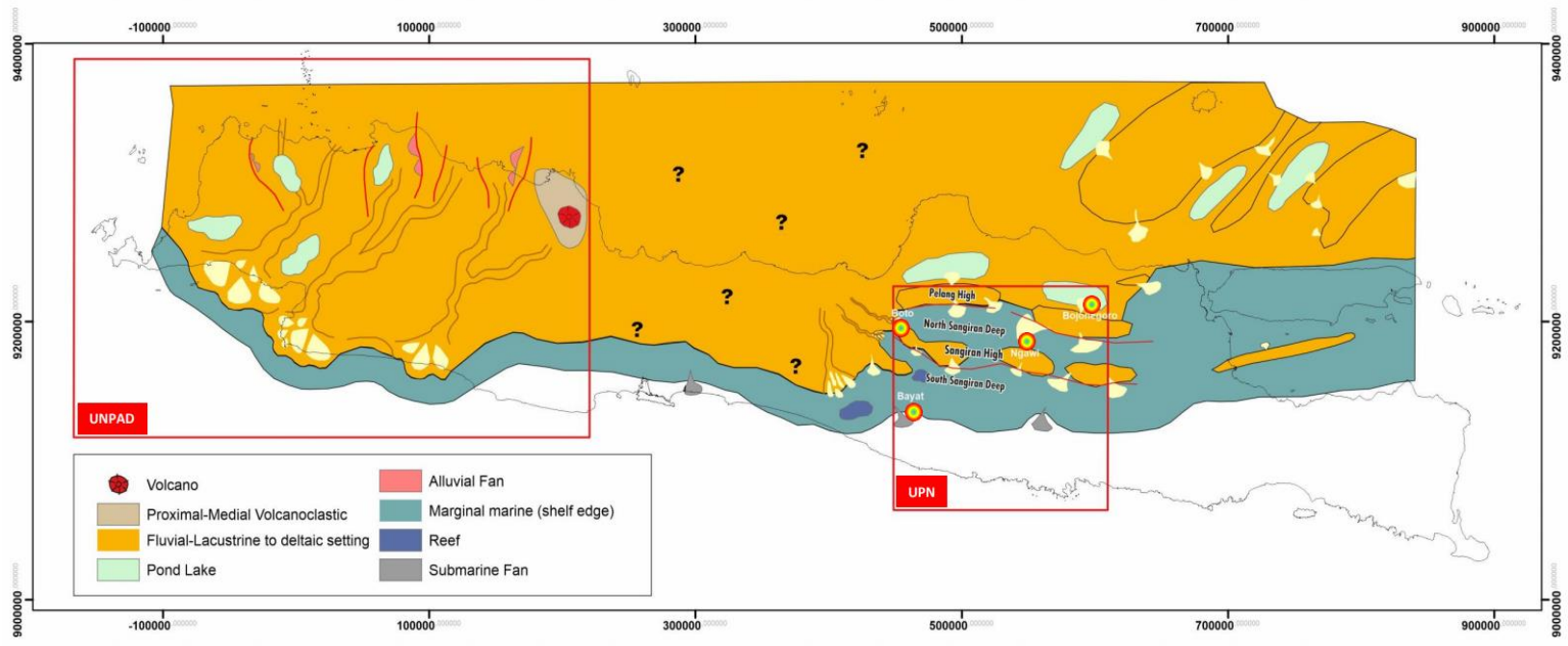

Early Eocene

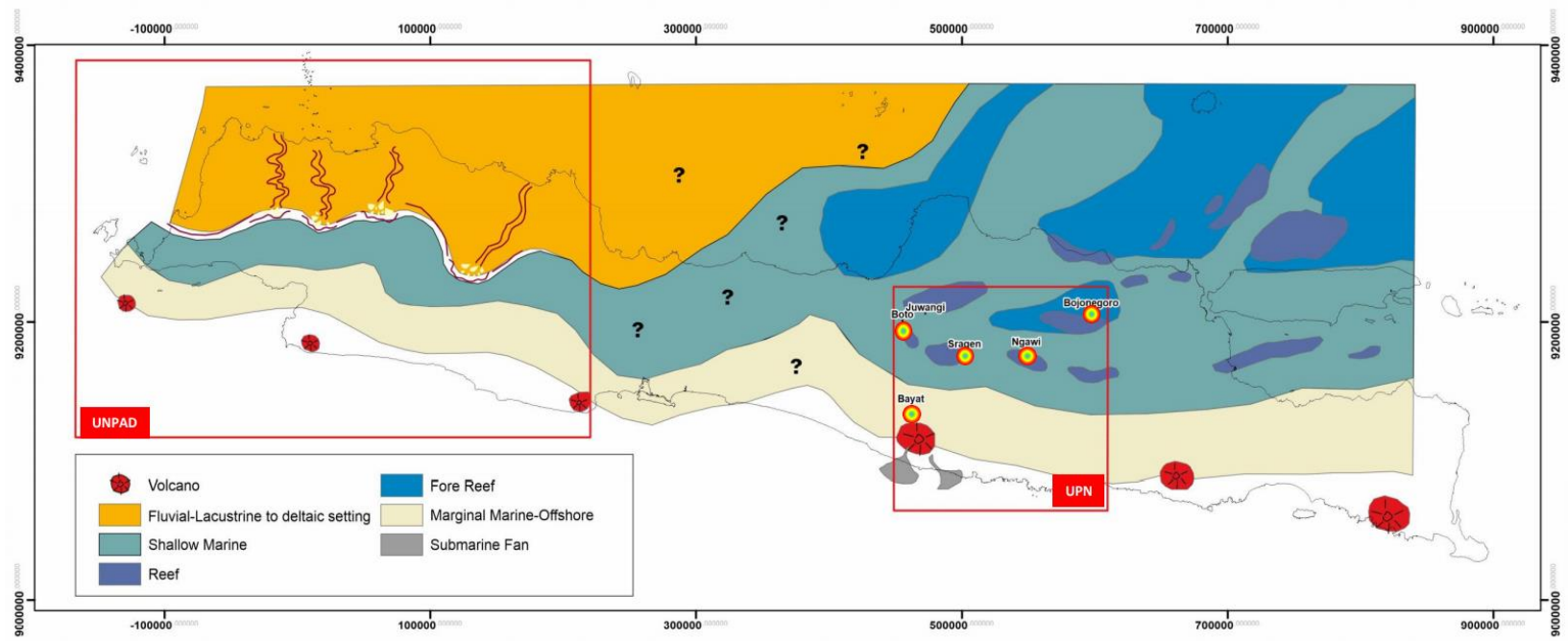

Late Oligocene

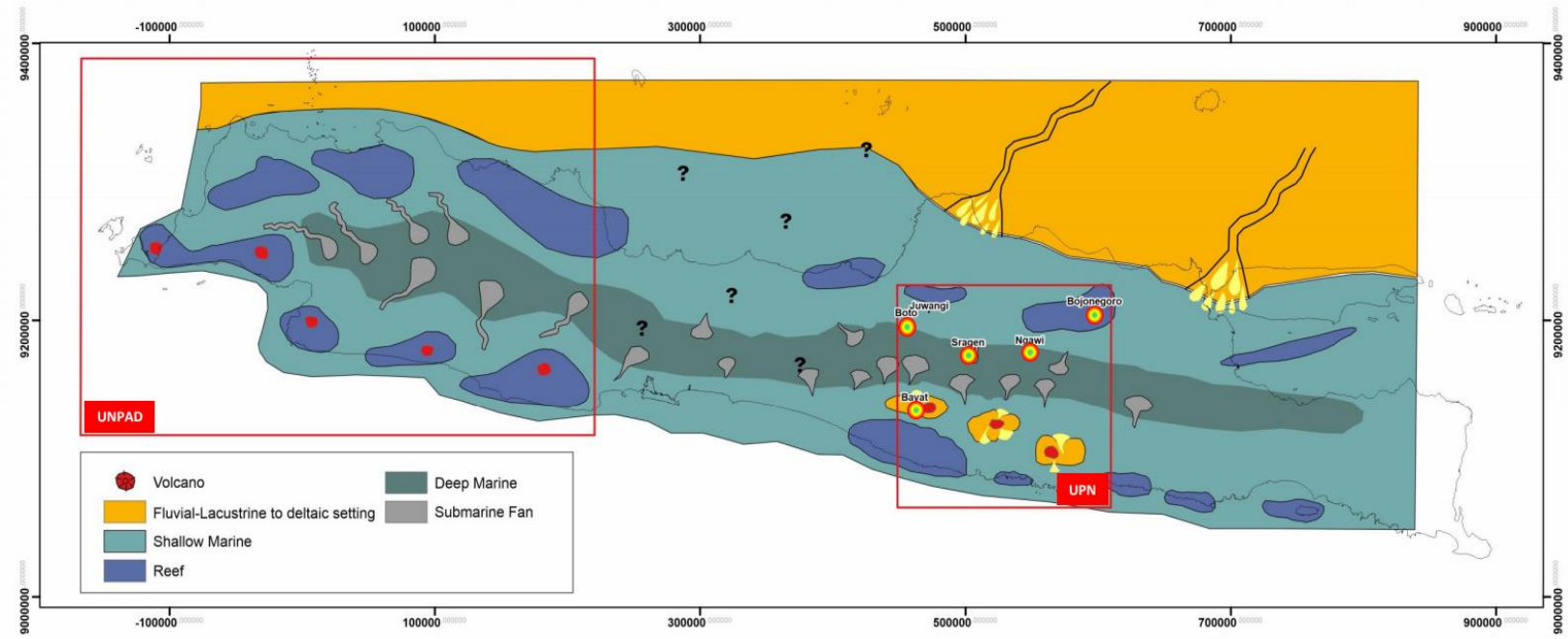

Middle Miocene 
Figure 15. The simplified cartoon of the Gross Depositional Environment (GDE) based on data integration from West Java (Bogor Trough area) and East Java (Kendeng Trough area) from a) Early Eocene, b) Late Oligocene, and c) Middle Miocene. These maps also incorporated interpretation from previous publications i.e., Hall et al. (2007), Hall and Smyth (2008), Lunt (2013) and Lunt (2019) (see text for the explanation).

The exposure of this limestone, with a presence of large Eulepidina is once reported in the Mrisi area (van Bemmelen, 1949 in Lunt, 2013), but the recent fieldworks were unable to locate the position of the outcrop and assumed that the exposure probably has long gone by the erosion.

In the northwest Java Basin, the transgression was also marked by the deposition of a thick sequence of limestone of Baturaja Fm. In the Bogor area, at the southern extend, the sea emergence northward and creates a favourable area for shallow marine and transition depositional systems such as Batuasih, followed by Rajamandala Fm. During this time, the southern mountain volcanic arc system was interpreted to be partially submerged as an underwater volcano in the western area. In the eastern area, the volcanic arc continues onshore and align relatively east west in the southern part of Java Island. At this period, the distance between the southern mountain was still considered far away from the Bogor and Kendeng area. This condition continued until the early Miocene. During this period, the Pelang Fm. is deposited as a shelfal deposit in the Kendeng area, whereas in contrast, western Java becomes a deep-sea realm with the deposition of Citarum Fm. (Figure 15b).

\section{Middle Miocene}

During the Middle Miocene, the foldthrust belt deformation was intensified with an average shortening rate of 25$50 \%$ from its original form (UPNYPertamina, 2020). This deformation created a flexural basin that separated the Bogor and Kendeng Trough from the adjacent basin of the northwest and northeast Java basins. Bogor and Kendeng Trough were started to form as a deep basin with possible multidirectional provenance were the major sediment provenance derived from Sundaland shelf margin in the north, dominated with arenite and volcanic material of southern mountains from the south. This period was marked with the deposition of thick deep-water deposits such as the Kerek Formation in the Kendeng area and the Jatiluhur and Cinambo Formations in the Bogor area. This thick deep-sea deposit was furthermore uplifted and partly thrusted, followed by the deposition of younger shallow marine deposits such as Kalibeng and Klitik in the east and Klapanunggal and Cantayan in the western area (Figure 15c).

\section{"Native" Petroleum System and Geological Risks in Bogor and Kendeng Troughs}

Figure 16 shows a compiled table of proposed petroleum elements in Bogor and Kendeng Trough. The prospective source rocks are derived from the 


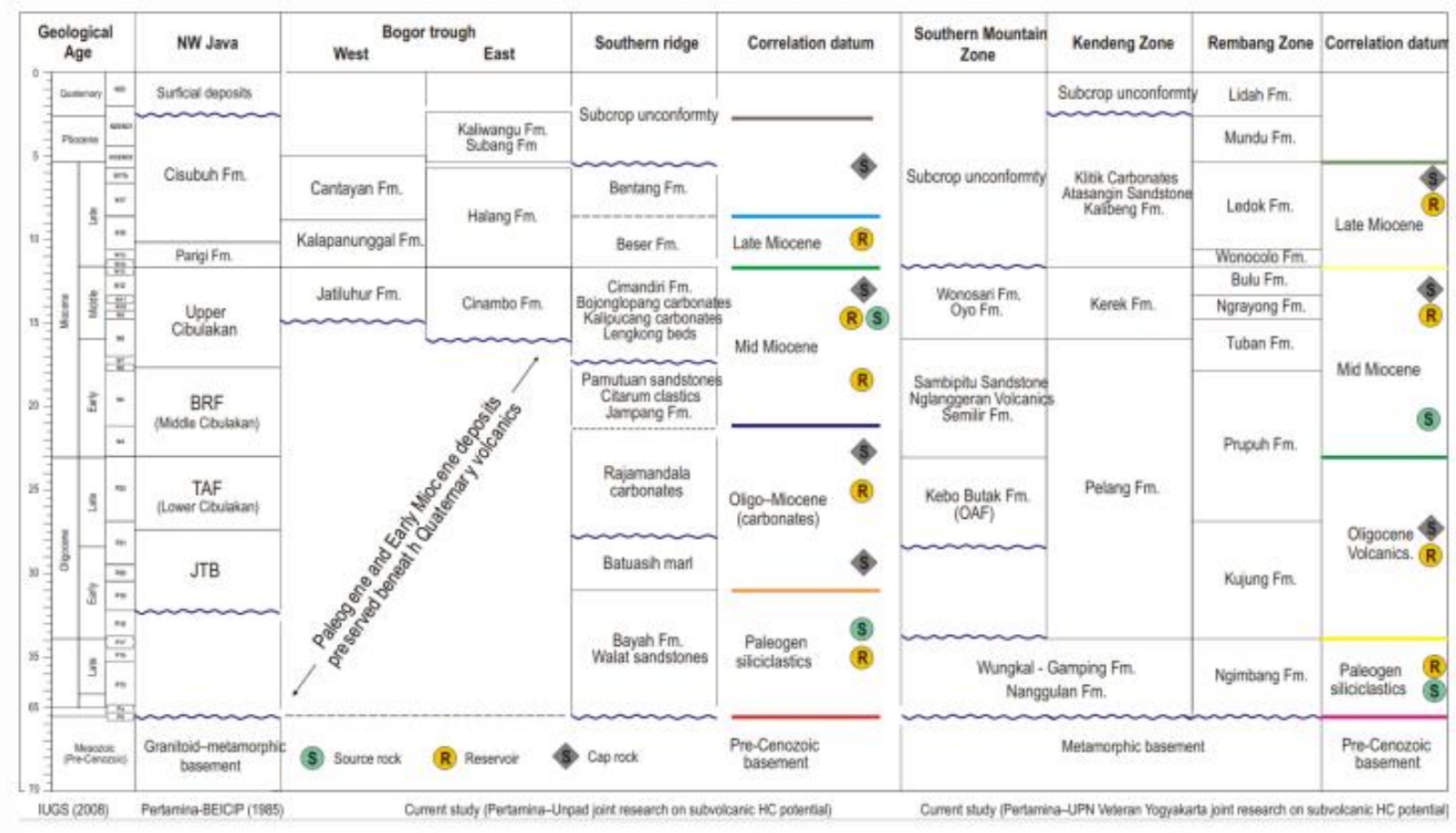

Figure 16. The proposed petroleum system elements in the Bogor and Kendeng Troughs (see text for the explanation).

terrestrial and transition environment from Paleogene units in the West Java, such as the Bayah, Walat and Batuasih Formations, which demonstrate mature source rock, with moderate to good TOC with kerogen Type II and III. In addition, the Neogene sample from the Cinambo Formation shows moderate to good TOC (0.72 -1.21 wt. \%).

The Paleogene siliciclastic such as Bayah and Walat Fm. and Oligocene Rajamandala Fm. could become a major potential reservoir rock. The other younger siliciclastic and volcaniclastic units (Seubert, 2015) could also be potential as reservoir rocks depend on their preserve porosity and permeability due to the intensive tectonic and burial. Furthermore, the widespread distribution of Subang and Kaliwangu Fm. shale shows their potential to become a regional seal rock.
In Eastern Java, The Paleogene equivalent Wungkal and Nanggulan Fm. underneath the Neogene unit in the Kendeng zone possibly act as primary potential source rock. The sample from the oldest rock exposed in the area, Pelang Fm., is still considered immature. The best candidate for reservoir rocks is included equivalent Wungkal and Nanggulan terrestrial to transition deposit and any sand unit in Pelang Fm. The regional shallow marine shale from Kalibeng Fm. is becoming a good candidate for the regional shale.

The proposed trapping mechanism in this studied basin is mostly a combination of stratigraphic and structural traps. The thrust and foldbelt system have a crucial control to form the structural closure and became a primary hydrocarbon conduit from the source rocks to the reservoir. This southerly dipping thrust system is 
becoming a major hydrocarbon pathway to the surface (Figure 17). There are still geological risk factors associated with the systems; in the Paleogene siliciclastic reservoir, some risks may be associated with imperfection in structural closures, limited thickness, and the limited extent of the caprock area. Magma intrusion may destroy or compartmentalize trap, and preexisting fault system and direct contact with magma may "overcook" source rock and loss of hydrocarbon charging. In the Oligo-Miocene Carbonate, longdistance migration, limited carrier beds, and fault conduit and lateral facies change. The other geological risk in the Neogene siliciclastic reservoir is poor porosity development in matrixrich volcanogenic sandstone.

\section{CONCLUSION}

Both Bogor and Kendeng Troughs contain active petroleum systems where HC were generated from Type II to III Kerogen, typical of organic material that were deposited in transition to shallow marine environment. The result suggests that these basins are separate from the neighbouring basins, The Northwest Java and Northeast Java Basins are characterized by more strictly terrigenous Type III Kerogen.

Bogor and Kendeng Troughs' ultimate source rocks came from deeply buried Paleogene stratigraphic unit (Bayah Fm. in Bogor Trough and unidentified Pre-Pelang Fm., e.g., equivalent to Wungkal-Gamping and Nanggulan Fm. in Kendeng Trough) with various potential reservoir rock of Paleogene to Neogene deposit. The contrasting
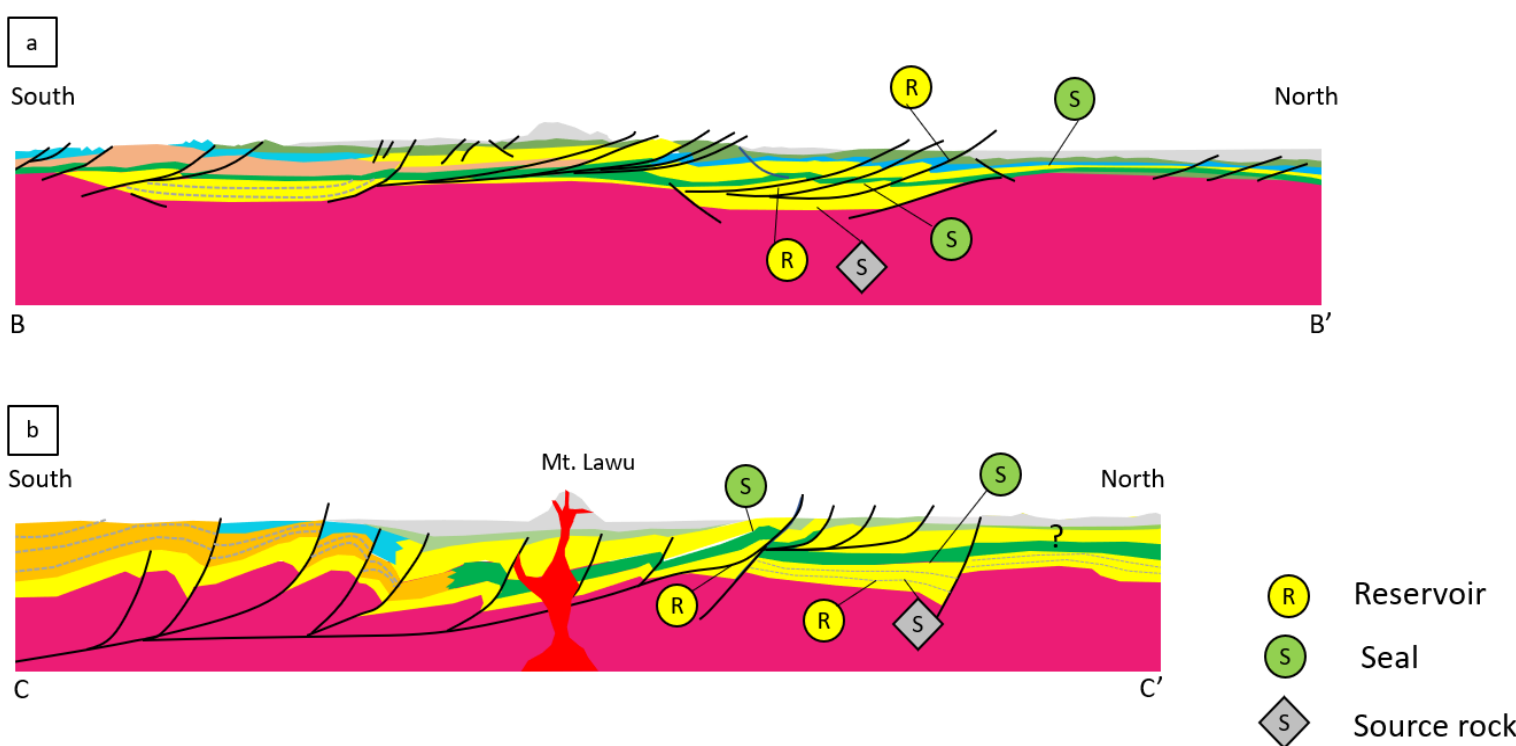

Figure 17. The cartooned section of structural reconstruction and interpreted regional geology and associated petroleum play a) Cijulang - Indramayu - Kromong section in Bogor Trough west Java and b) Wonogiri- Gunung Lawu - Purwodadi section in Kendeng Trough East Java (UNPAD-Pertamina, 2020; UPN-Pertamina, 2020). See Fig. 1 for the location. 
subsurface configuration between Bogor and Kendeng Troughs mainly concerns the fold-thrust belt basement involvement and the tectonic shortening effect on the formerly rift basin.

The implication for the petroleum play: the sub-thrust and over-thrust plays combined with the stratigraphic play were expected to develop in Bogor Trough. On the other hand, more traditional rift deposits and paleo high limestone development (e.g., equivalent Pelang Fm.) could become the most expected prospective target in Kendeng Trough.

\section{ACKNOWLEDGEMENT}

PERTAMINA Research and Technology Innovation (RTI) provided funding and resources for this study through the University ideation program to Universitas Padjajaran (UNPAD) and Universitas Pembangunan Nasional Veteran (UPN Veteran). This manuscript is dedicated to the memory of our dear teacher and advisor, Dr. Rudy Ryacudu, who passed away while this paper was being prepared. May his legacy in regional geology last forever.

\section{REFERENCES}

Abdurrokhim, A. and Ito, M., 2013. The role of slump scars in slope channel initiation: A case study from the Miocene Jatiluhur Formation in the Bogor Trough, West Java. Journal of Asian Earth Sciences, 73, p. 68-86.

Adhiperdana, $\quad$ B.G., 2018. Sedimentological study of fluvial succession of the Eocene - Oligocene Bayah Formation, West Java; reconstruction of palaeohydrological features of an ancient fluvial system using empirical equations developed from modern fluvial systems in Indonesia Islands. PhD Thesis, Chiba University, Japan, 217 pp.

Baumann, P., De Genevraye, P., Samuel, L., Mudjito and Sajekti, S., 1973. Contribution to The Geological Knowledge of Southwest Java. Proceedings of Indonesian Petroleum Association, Second Annual Convention, p. 105-108.

Clements, B., Hall, R., Smyth, H.R. and Cottam, M.A., 2009. Thrusting of a volcanic arc, a new structural model for Java. Petroleum Geoscience, 15(2), p. 159-174.

Doust, H. and Noble, R.A., 2008. Petroleum systems of Indonesia. Marine and Petroleum Geology, 25, p. 103-129.

Doust, H., 2017. Petroleum systems in Southeast Asian Tertiary basins. Bulletin of Geological Society of Malaysia, 64(1), p. 1-16.

Gani, R.M.G., Firmansyah, Y. and Pamekas, S.F, 2020. Stratigraphic analysis of Rajamandala Formation and Citarum Formation based on outcrops data. Journal of Geological Sciences and Applied Geology, 4(1), p. 40-47.

Hall, R. 1996. Reconstructing Cenozoic SE Asia. In: R. Hall and D.J. Blundell (Eds), Tectonic Evolution of SE Asia. Geological Society, London, Special Publication 106, p. 153-184.

Hall, R., Clements, B., Smyth, H.R. and Cottam, M.A., 2007. A New 
interpretation of Java's structure. Proceedings of Indonesian Petroleum Association, Thirty-First Annual Convention and Exhibition.

Hall, R. and Smyth, H.R., 2008. Cenozoic arc processes in Indonesia: identification of the key influences on the stratigraphic record in active volcanic arcs. In: A.E. Draut, P.D. Clift and D.W. Scholl (Eds), Formation and Applications of the Sedimentary Record in Arc Collision Zones. Geological Society of America, Special Publication 436 , p. 27-54.

Hamilton, 1979. Tectonics of the Indonesian region, US Geological Survey Professional Paper 1078, p. 100-156.

Huang, W. Y. and Meinschein, W. G., 1979. Sterols as ecological indicators, Geochimica et Cosmochimica Acta, 43, p. $739-745$.

Irwansyah, K., Anwar M and Basuki, N.I., 2011. Karakterisasi batuan karbonat Formasi Rajamandala berdasarkan foraminifera besar di daerah Padalarang, Jawa Barat. Proceedings of Joint Convention 36th HAGI and 40th IAGI Annual Convention, Makassar, JCM2011-103, $24 \mathrm{pp}$.

Katili, J.A., 1973. Geochronology of West Indonesia and its Implication on Plate Tectonics. Tectonophysics, 19, p. 195-212.

Katili, J.A., 1975. Volcanism and plate tectonics in the Indonesian island arcs. Tectonophysics, 26(3), p. 165-188.
Koesoemadinata, R.P. and Siregar, S., 1984. Reef Facies Model of the Rajamandala Formation, West Java. Proceedings of Indonesian Petroleum Association Convention, 18 pp.

Lunt, P., 2013. The sedimentary geology of Java. Indonesian Petroleum Association, Special Publication, Jakarta, 347 pp.

Lunt, P. 2019. The origin of the East Java Sea basins deduced from sequence stratigraphy. Marine and Petroleum Geology, 105, p. 17-31.

Martodjojo, S., 1984. Bogor Basin Evaluation, West Java (Evolusi Cekungan Bogor, Jawa Barat). Doctoral Thesis, Institute of Technology of Bandung, Bandung, 238 pp.

Martodjojo, S., 2003. Evolusi Cekungan Bogor. Institute of Technology, Bandung, 258 pp.

Metcalfe, I., 2017. Tectonic evolution of Sundaland. Bulletin of Geological Society of Malaysia, 63, p. 27-60.

Morley, R. J., 2012. A review of the Cenozoic paleoclimate history of Southeast Asia. In: D. Gower, K. Johnson, J. Richardson, B. Rosen, L. Ruber and S. Williams (Eds), Biotic Evolution and environmental change in southeast Asia. Cambridge University Press, Cambridge, UK, p. 79-114.

Muljana, B., Watanabe, K. and Rosana, M.F., 2012. Petroleum system in back arc basin Majalengka sub-basin Indonesia. World Academy of Science, Engineering and Technology, 62, p. 1792-1800. 
Peters, K.E. and Moldowan, J.M., 1993. The Biomarker Guide. Interpreting Molecular Fossils in Petroleum and Ancient Sediments. Prentice Hall, New Jersey.

Prasetyadi, C., Rachman, M.G., Hapsoro, S.E., Shirly, A., Gunawan, A. and Purwaman, I., 2016. Seismic based structural mapping of RMKS Fault Zone: Implication to hydrocarbon accumulation in East Java Basin. Proceedings of GEOSEA XIV and 45th IAGI Annual Convention, p. 104-107.

Pubellier, M. and Morley, C.K., 2013. The basins of Sundaland (SE Asia): Evolution and boundary conditions. Marine and Petroleum Geology, 58, p. 555-578

Satyana, A.H. and Purwaningsih, M.E.M., 2003. Geochemistry of The East Java Basin: New observations on oil grouping, genetic gas types and trends of hydrocarbon habitats. Proceedings of Indonesian Petroleum Association Twenty-Ninth Annual Convention \& Exhibition, p. 585-607.

Satyana, A.H., 2014. Subvolcanic hydrocarbon prospectivity of Java: opportunities and challenge. Proceedings of 39th Annual Convention Indonesian Association of Geophysicists (HAGI), Solo, 4 pp.

Satyana, A.H., 2016. The emergence of Pre-Cenozoic petroleum system in East Java Basin: Constraints from new data and interpretation of tectonic reconstruction, deep seismic, and geochemistry, Proceedings of Indonesian Petroleum Association Fortieth Annual Convention \& Exhibition, IPA16-573-G, 30 pp.
Sekti, R.P., F. Hakiki, A.N. Derewetzky, C.J. Strohmenger, S.M. Fullmer, T. Simo, B. Sapiie and D. Nugroho, 2011. Facies analysis and sequence stratigraphy of Tertiary subsurface (Cepu Block) and surface (Rajamandala Limestone) carbonates of Java, Indonesia. Proceedings of Indonesian Petroleum Association (IPA), 35th Annual Convention, Jakarta, IPA11-G063, p. 1-15.

Seubert, B.W., 2015. Volcaniclastic petroleum systems - Theory and examples from Indonesia. Proceedings of Indonesian Petroleum Association, Thirty-Ninth Annual Convention \& Exhibition, IPA15-G-026, p. 1-19.

Simo, T., Weidmer, M., Van Simaeys, S., Sekti, R., Van Gorsel, H., Strohmenger, C. and Derewetzky, A., 2011. Sequence stratigraphic correlation and sedimentological implications, East Java Basin: comparisons and lessons learned from outcrop and subsurface studies. Proceedings of Indonesian Petroleum Association, Thirty-Fifth Annual Convention, IPA11-G-234, p. 1-9.

Smyth, H., Hall, R., Hamilton, J., and Kinny, P., 2005. East Java: Cenozoic basins, volcanoes, and ancient basement. Proceedings of Indonesian Petroleum Association, 30th Annual Convention, p. 251266.

Sribudiyani, Muchsin, N. and Ryacudu, R., 2003. The collision of the East Java microplate and its implication for hydrocarbon occurrences in the East Java Basin. Proceedings of Indonesian Petroleum Association, 29th Annual Convention, p. 335-346. 
UNPAD-Pertamina, 2020. Final Report of the Petroleum prospect in Bogor Trough, West Java.

Fakultas Teknik Geologi UNPAD Pertamina INV 2020, 61 pp. (unpublished).

UPNY-Pertamina, 2020. Final Report of the Petroleum prospect in Kendeng Trough, East Java. Fakultas Teknologi Mineral UPN - Pertamina INV 2020, 774 pp. (unpublished).

van Gorsel, J.T., 2018. Bibliography of the geology of Indonesia and surrounding areas, edition 7.0, III. Java, Madura, and Java Sea, 296 pp.

Waltham, D., Hall, R., Smyth, H.R. and Ebinger, C.J., 2008. Basin formation by volcanic arc loading. In: A.E. Draut, P.D. Clift \& D.W. Scholl (Eds.), Formation and applications of the sedimentary record in arc collision zones. Geological Society of America, Special Paper 436, p. 11-26.
Yulianto, I., Hall, R., Clements, B. and Elders, C., 2007. Structural and stratigraphic evolution of the offshore Malingping Block, West Java, Indonesia. Proceedings of Indonesian Petroleum Association, 31st Annual Convention, p. 171-183.

Warren, J., 2018. Geological characterization of reservoir quality in Tertiary-age carbonate reservoirs across Southeast Asia. FOSI Webinar Series, available online at: (186) FOSI Talk 8 August Carbonate Reservoir SE Asia by John Warren - YouTube

Wibowo, U.P. and Kapid, R., 2014. Biostratigrafi nannoplankton daerah Rajamandala. Jurnal Geologi Sumberdaya Mineral 15, 4 (203), p. 185-194. 